\title{
Cephalometric analysis: concordance between software
}

\author{
Análise cefalométrica: concordância entre softwares
}

Thereza Raquel Garcia Silva CORREIA'

Lorena Marques Ferreira de SENA'

José Sandro Pereira da SILVA ${ }^{1}$

Hallissa Simplício Gomes PEREIRA'

\section{ABSTRACT}

\section{Objective}

To evaluate the agreement between cephalometric measures obtained from two different software programs: Dolphin Imaging $11.7^{\circledR}$ and Radiocef Studio $2^{\circledR}$.

\section{Methods}

30 digital lateral teleradiographies (200 dpi, 2100 × 2092 pixels) were analyzed on each of the software programs through demarcation of 11 cephalometric points by a single calibrated examiner. Then, the generated cephalometric magnitudes were statistically correlated by means of the intraclass correlation coefficients (ICC). Then 10 randomly selected radiographies were retraced on each of the programs in order to evaluate the intra-examiner concordance after a time interval of 08 days.

\section{Results}

The SNB and Pog-NB magnitudes showed strong concordance between the software, while the SNA, ANB, 1-NA, 1-NB, 1.NB, 1.1 and Go-Gn. SN magnitudes unveiled moderate concordance. Only the 1.NA magnitude showed weak concordance.

\section{Conclusion}

The software can be interchangeably applied in clinical practice.

Indexing terms: Cephalometry. Orthodontics. Software.

\section{RESUMO}

Objetivo

Avaliar a concordância entre grandezas cefalométricas obtidas através dos softwares Dolphin Imaging $11.7^{\circledR}$ e Radiocef Studio $2^{\circledR}$.

\section{Métodos}

Trinta telerradiografias laterais digitais (200 dpi, 2100 × 2092 pixels) foram analisadas em cada um dos softwares através da demarcação de 11 pontos cefalométricos por um único examinador calibrado. As grandezas cefalométricas geradas foram correlacionadas estatisticamente por meio dos coeficientes de correlação intra classe (CCI). A fim de avaliar a concordância intra-examinador, 10 telerradiografias selecionadas aleatoriamente foram retraçadas em cada um dos softwares após um intervalo de 8 dias.

\section{Resultados}

As grandezas SNB e Pog-NB mostraram forte concordância entre os softwares, enquanto que as grandezas SNA, ANB, 1-NA, 1-NB, 1.NB, 1.1 e Go-Gn.SN revelaram concordância moderada. Somente a grandeza 1.NA demonstrou fraca concordância.

\section{Conclusão}

Os softwares podem ser aplicados intercambiavelmente na prática clínica.

Termos de indexação: Cefalometria. Ortodontia. Software.

\section{INTRODUCTION}

For many years, manual cephalometric tracing was the only method capable of measuring cephalometric magnitudes. For its execution, a transparent acetate sheet is superimposed above the printed teleradiography. The main anatomic structures and cephalometric points are identified using a pencil, thereby originating lines and plans that can be measured ${ }^{1}$.

In 1969, Ricketts ${ }^{2}$ demonstrated computerized cephalometric tracing. From that point onwards, various specific software for cephalometric analyses were designed:

\footnotetext{
${ }^{1}$ Universidade Federal do Rio Grande do Norte, Departamento de Odontologia. Av. Senador Salgado Filho, 1787, Lagoa Nova, 59056-000, Natal, RN, Brasil. Correspondência para / Correspondence to: LMF SENA. E-mail: <lorena.mf@hotmail.com>.
} 
Dentofacial Planner ${ }^{\circledR}$, Viewbox ${ }^{\circledR}$, Dophin Imaging ${ }^{\circledR}$, Orto Manager ${ }^{\circledR}$, Radiocef Studio ${ }^{\circledR}$, and Cef- $X^{\circledR}$, among others. The use of these software programs has brought many advantages such as time optimization and the possibility to store, manipulate and recover images on computers ${ }^{1,3-4}$. Dolphin Imaging ${ }^{\circledR}$ software was designed in the 1980's by the Dolphin Imaging and Management Solutions Company (California, United States), and won market share in the field of Dentistry on a global scale, both in the clinical scope and in the areas of research and teaching. In Brazil, it was shown for the first time during the $2^{\text {nd }}$ Computer Science Symposium on Orthodontics, thereby boosting the use of this type of technology within Brazilian Orthodontics ${ }^{5}$. Its usage in practice promotes immediate reading of the linear and angular magnitudes of the cephalogram, but entails a high cost. For many people, this factor prevents them from purchasing it. In 1994, Radiocef Studio ${ }^{\circledast}$ software was designed by the RadioMemory ${ }^{\circledR}$ Company (Belo Horizonte, Brazil) and revolutionized implantation of computerized cephalometry in the country, thereby becoming one of the most traded and used software programs until the present day $^{6}$. The more accessible cost of the product attracted a big part of Dental Radiology Centers in the country.

Given the popularization of these software programs, it is of crucial importance that they are evaluated in relation to reproducibility, and consequently, their clinical and scientific applicability. Therefore, this study has the objective of evaluating concordance among the cephalometric magnitudes obtained through the Radiocef Studio $2^{\circledR}$ and Dolphin Imaging $11.7^{\circledR}$ software programs.

\section{METHODS}

This project was approved by the Research Ethics Committee under the number 752.476 .

After approval, 30 lateral teleradiographies (pretreatment) were selected from the archives on the subject of Oral and Maxillofacial surgery of the Federal University of Rio Grande do Norte, following the ensuing inclusion criteria: both genders, aged between 15 and 45 years, showing all teeth present, from first to first permanent molar, and with right posture during radiography procurement. According to Jacobson and Jacobson ${ }^{7}$, these lateral teleradiographies should be performed with the patient's head immobilized by a cephalostat guided by the Frankfort Horizontal plane, parallel to the ground and perpendicular to the midsagittal plane. Teleradiographies showing orthodontic appliances, pathologies, dental anomalies and deciduous teeth were excluded. These criteria were evaluated on panoramic radiographs acquired at the same time of the teleradiograph.

Each one of the teleradiographies was analyzed in the Radiocef Studio $2^{\circledR}$ (Radiomemory ${ }^{\circledR}$, Belo Horizonte, Minas Gerais, Brazil) and Dolphin Imaging 11.7 ${ }^{\circledR}$ (Dolphin Imaging and Management Solutions ${ }^{\circledR}$, Anaheim, California, United States) 2D software through demarcation of 11 cephalometric points by a single examiner specialized in Orthodontics. The examiner was allowed to use any of the software's image enhancing features to better visualize structures. In the first step, the examiner was calibrated by performing five sequential cephalometric analyses on each one of the software programs until the techinique was mastered.

All cephalometric analyzes were performed in the same setting, under the same lighting conditions, and using the same computer monitor with a 19-inch flat screen in order to minimize possible errors due to different resolutions. All image calibrations were standardized at 200 dpi. Only images presenting quality digital and size of 2100 x 2092 pixels were analyzed. All image acquisitions were carried out using a Kodac $8000{ }^{\circledR}$ appliance (Carestream Health Inc., Rochester, New York, 14-bit grayscale).

The following cephalometric points were demarcated:

- $\mathrm{S}$ - The pituitary fossa image center;

- $\mathrm{N}$ - The foremost point of the frontonasal suture;

- A - The deepest point in the maxillary concavity between the anterior nasal spine and the alveolar ridge;

- B - The deepest point of the anterior concavity of the mandibular symphysis;

- Gn - Most anterior and inferior point of the mentonian symphysis;

- Go - Point where the bisector of the angle formed by the tangent at the posterior edge of the mandible branch and the tangent at the inferior limit of the mandible body intersects the mandibular line;

- Pog - The foremost point of the border of the mento in the sagittal plane;

- lis - Point in the incisal edge of the upper central incisor;

- Ais - Root apex of the upper central incisor;

- lii - Point in the incisal edge of the lower central incisor;

- Aii - Root apex of the lower central incisor.

The cephalometric magnitudes automatically generated by each one of the software programs after 
cephalometric point demarcation are listed below:

- SNA: Angle formed between the SN and NA lines;

- SNB: Angle formed between the SN and NB lines;

- ANB: Angle formed between the NA and NB lines;

- 1.1: Angle formed by the intersection of the long axis of the upper incisor with the long axis of the lower incisor;

- 1.NB: Angle between the long axis of the lower incisor and the NB line;

- 1.NA: Angle between the long axis of the upper incisor and the NA line;

- 1-NB: Distance between the foremost part of the lower incisor and the NB line;

- 1-NA: Distance between the foremost part of the upper incisor and the NA line;

- SN.GoGn: Angle between the mandibular plane (Go-Gn) and the SN line;

- Pog-NB: Distance from pogonion to NB, parallel to the Frankfurt plane.

The data bank for the research was built in the SPSS ${ }^{\circledR}$ software platform (Statistical Package for Social Sciences), version 22.0 for Windows ${ }^{\circledR}$. Next, a descriptive analysis of the cephalometric magnitudes generated by each one of the software programs was produced with regard to mean, median, standard deviation and minimum and maximum values. Lastly, the degree of concordance between the two programs was analyzed by the means of the intraclass correlation coefficients (ICC).

In order to evaluate the intra-examiner concordance, 10 randomly selected radiographies were retraced on each one of the programs after a time interval of 08 days. The results were evaluated through the intraclass correlation coefficients (ICC).

\section{RESULTS}

The degree of concordance between the results obtained by the same examiner in two distinct moments using the same software was given by the intraclass correlation coefficients, according to Table 1. For Radiocef ${ }^{\circledR}$, two magnitudes (1.NA and 1.1) showed values below 0.3, thereby indicating weak intra-examiner concordance. A similar result was found for Dolphin ${ }^{\circledR}$ in four magnitudes: 1-NA, 1.NA, 1-NB and 1.NB.

Table 2 shows a descriptive analysis of the data related to the cephalometric magnitudes with regard to mean (Me), median (Md), standard deviation (SD) and minimum and maximum values (Min-Max) for Radiocef ${ }^{\oplus}$ and Dolphin ${ }^{\circledR}$ software.

Table 1. Intra-examiner concordance for the research software $(n=10)$

\begin{tabular}{ccc}
\hline & Radiocef $^{\circledR}$ ICC & Dolphin® ICC \\
\hline SNA & 0.468 & 0.616 \\
SNB & 0.956 & 0.426 \\
ANB & 0.651 & 0.501 \\
1-NA & 0.566 & -0.100 \\
1.NA & 0.093 & 0.112 \\
1-NB & 0.892 & -0.184 \\
1.NB & 0.904 & -0.335 \\
Pog-NB & 0.964 & 0.509 \\
1.1 & 0.206 & 0.946 \\
Go-Gn.SN & 0.957 & 0.404 \\
\hline
\end{tabular}

Note: ICC: intraclass correlation coefficient.

Table 2. Characterization of the samples analyzed in Radiocef $(R)$ and Dolphin $尺$ software $(D)(n=30)$.

\begin{tabular}{|c|c|c|c|c|c|}
\hline & $\begin{array}{l}\text { Mean } \\
\text { R/D }\end{array}$ & $\begin{array}{l}\text { Median } \\
\text { R/D }\end{array}$ & $\begin{array}{l}S D \\
R / D\end{array}$ & $\operatorname{Min}-\operatorname{Max}$ & $\begin{array}{c}\text { Min - Max } \\
\text { D }\end{array}$ \\
\hline SNA $\left({ }^{\circ}\right)$ & $82.5 / 85.7$ & $82.1 / 85.7$ & $4.2 / 5.7$ & $72.9-93.9$ & $65.3-98.5$ \\
\hline $\operatorname{SNB}\left({ }^{\circ}\right)$ & $80.6 / 81$ & $80.4 / 81$ & $3.6 / 3.9$ & $75.5-88.2$ & $75.6-90.7$ \\
\hline $\operatorname{ANB}\left({ }^{\circ}\right)$ & $1.8 / 4.3$ & $3.0 / 4.3$ & $3.2 / 4.2$ & $-4.8-5.8$ & $-2.2-22.5$ \\
\hline 1-NA (mm) & $5.9 / 5.3$ & $6.0 / 5.3$ & $4.8 / 5.4$ & $-0.8-16.0$ & $-4.9-23.9$ \\
\hline 1.NA $\left(^{\circ}\right)$ & $34.4 / 24$ & $28.6 / 24$ & $34.4 / 12.6$ & $6.9-160.9$ & $2.6-63.2$ \\
\hline 1-NB (mm) & $4.9 / 4.9$ & $4.6 / 4.9$ & $2.1 / 2.7$ & $1.7-10.8$ & $1.9-16.1$ \\
\hline 1.NB $\left(^{\circ}\right)$ & $27.2 / 25.4$ & $27.3 / 25.4$ & $6.0 / 11.8$ & $12.9-40.7$ & $13.9-85.5$ \\
\hline Pog-NB (mm) & $2.1 / 2.5$ & $2.3 / 2.5$ & $2.2 / 2.4$ & $-2.87-6.56$ & $-2.4-9.6$ \\
\hline $1.1\left(^{\circ}\right)$ & $120.5 / 129.7$ & $122.7 / 129.7$ & $21.0 / 9.3$ & $39.7-146.3$ & $113.6-150.6$ \\
\hline Go-Gn.SN $\left(^{\circ}\right)$ & $30.2 / 30.3$ & $30.9 / 30.3$ & $5.70 / 13.3$ & $20.9-41.3$ & $19.3-96.4$ \\
\hline
\end{tabular}

Note: SD: standard deviation; Min - Max: minimum and maximum values.

The degree of concordance between Radiocef Studio $2^{\circledR}$ and Dolphin Imaging $11.7^{\circledR}$ software was evaluated by the intraclass correlation coefficients (ICC), as shown in Table 03. Only the 1.NA magnitude showed 
less than 0.3 ICC, thereby suggesting weak concordance among groups.

Table 3. Concordance between Radiocef ${ }^{\circledR}$ and Dolphin ${ }^{\circledast}$ software $(n=30)$.

\begin{tabular}{cc}
\hline & ICC \\
\hline SNA & 0.602 \\
SNB & 0.919 \\
ANB & 0.627 \\
1-NA & 0.436 \\
1.NA & 0.048 \\
1-NB & 0.484 \\
1.NB & 0.319 \\
Pog-NB & 0.874 \\
1.1 & 0.417 \\
Go-Gn.SN & 0.491 \\
\hline
\end{tabular}

Note: ICC: intraclass correlation coefficient.

\section{DISCUSSION}

Technology growth in the dental area has drawn the attention of researchers to test new things. Within the field of Orthodontics, one should highlight computerized cephalometric tracing obtained with the aid of software, which has been becoming even more present in scientific studies and in clinical practice ${ }^{5-6,8}$.

Given the aforementioned need, it became convenient to compare Dolphin ${ }^{\circledR}$ and Radioce ${ }^{\circledR}$ software, which generally showed good concordance with each other. Other authors have compared different software among them and observed similar results. Erkan et al. ${ }^{8}$ compared Dolphin ${ }^{\circledR}$, Vistadent ${ }^{\circledast}$, Nemoceph ${ }^{\circledast}$ and Ceph Quick $^{\circledast}$ software, and did not find statistically significant difference among them. In the study of Vasconcelos et al. ${ }^{6}$, Radiocef ${ }^{\oplus}$ was compared to Dental Planner ${ }^{\circledR}$, but also no statistically significant difference was found. Furthermore, Glaros et al. ${ }^{9-10}$ compared Dolphin Imaging ${ }^{\circledR}$ and Vistadent ${ }^{\circledR}$ software. The authors noticed that the cephalometric magnitudes of hard tissue did not show statistically significant difference between the software. However, there was statistically and clinically significant difference in the measurement of the facial angle with regard to soft tissue magnitudes.

Only the 1.NA magnitude among the ten magnitudes evaluated in this study showed weak concordance between the software $(I C C<0.3)$. The majority of the magnitudes denoted moderate concordance $(0.3 \leq I C C \leq 0.699)$, while two showed strong concordance (ICC $\geq 0.7)$. It is interesting to notice that magnitudes involving demarcating points in the region of incisor teeth (1.NA, 1-NA, 1.NB, 1-NB and 1.1) showed lower intraclass correlation coefficients. Sena et al. ${ }^{11}$ and Silveira and Silveira ${ }^{12}$ reported results with a certain degree of similarity. The authors observed that points in the incisor teeth region are difficult to locate, in addition to the magnitudes related to them having low reliability. For Vasconcelos et al. ${ }^{6}$, the main deterrent noticed in locating incisive dental apex points occurs because the digital image produces gray shades that blend into each other in this region. According to Jabbal et al. ${ }^{13}$, orthodontic treatment can anteriorly or posteriorly force the lower incisors both in body and in a tipping motion, and this is monitored by comparing lower incisor angulation to the mandibular border using consecutive lateral cephalometric radiographs. Consequently, significant differences in demarcating incisor teeth may influence the therapeutic conduct of professionals ${ }^{12}$. Vasconcelos et al. ${ }^{6}$ highlight that an appropriate way to fix this problem is to improve the image quality in this region by using high-resolution monitors, capable of enhancing visualization of details in the image.

Another interesting finding is linked to the results of the intra-examiner concordance, because all the magnitudes that showed weak intra-examiner concordance independent of the software used, involve demarcation of incisor teeth points, thereby corroborating the main findings of this study.

Lastly, according to the cephalometric data evaluation, it is possible to consider that Dolphin Imaging $11.7^{\circledR}$ and Radiocef ${ }^{\circledR}$ software agree with each other. Thus, when purchasing one of them, it is interesting to consider an analysis of other characteristics such as: financial investment, archiving, transmission of documents and working time required by each one, given that they both perform the same task.

\section{CONCLUSION}

The results denote concordance between the two software programs for the majority of the analyzed cephalometric magnitudes. Therefore, they both can be interchangeably applied in clinical practice.

\section{Collaborators}

TRGS CORREIA and LMF SENA were responsible for writing the article, analyzing and interpreting the data. JSP SILVA was responsible for the conception, design of the research and review of the article. HSG PEREIRA was responsible for conception, designing of the research, data analysis and article review. 


\section{REFERENCES}

1. Leonardi R, Giordano D, Maiorana F, Spampinato C. Automatic cephalometric analysis: a systematic review. Angle Orthod. 2008;78(1):145-151. doi: 10.2319/120506-491.1

2. Ricketts RM. Introducing computerized cephalometrics. Denver: Rocky Mountain Data Systems, Inc.; 1969.

3. Chen SK, Chen YJ, Yao CC, Chang HF. Enhanced speed and precision of measurement in a computer-assisted digital cephalometric analysis system. Angle Orthod. 2004;74(4):5017.doi. 10.1043/0003-3219(2004)074<0501:ESAPOM>2.0. $\mathrm{CO} ; 2$

4. Tsorovas G, Karsten AL. A comparison of hand-tracing and cephalometric analysis computer programs with and without advanced features - accuracy and time demands. Eur J Orthod. 201;32(6):721-8. doi: 10.1093/ejo/cjq009

5. Paixão MB, Sobral MC, Vogel CJ, Araújo TM. Comparative study between manual and digital cephalometric tracing using Dolphin Imaging software with lateral radiographs. Rev Dental Press Ortodon Ortop Facial. 2010;15(6):123-30. doi: 10.1590/ S2176-94512010000600016

6. Vasconcelos MHF, Janson G, Freitas MR, Henriques JFC. Evaluation of a cephalometric software. Rev Dental Press Ortodon Ortop Facial. 2006;11(2):44-54. doi: 10.1590/S141554192006000200007

7. Jacobson A, Jacobson RL. Radiograph cephalometry: from basics to 3-D imaging. 2 ed. Canadá: Quintessence Publishing; 2006.
8. Erkan M, Gurel HG, Nur M, Demirel B. Reliability of four different computadorized cephalometric analysis programs. Eur J Orthod. 2012;34(3):318-21. doi: 10.1093/ejo/cjs074

9. Glaros AG, Gregston MD, Kula T, Kula K, Hardman P. A comparison of conventional and digital radiographic methods and cephalometric analysis software I: hard tissue. Semin Orthod. 2004;10(3):204-11. doi: 10.1259/dmfr/15644321

10. Glaros AG, Gregston MD, Kula T, Kula K, Hardman P. A comparison of conventional and digital radiographic methods and cephalometric analysis software II: soft tissue. Semin Orthod. 2004;10(3):212-9. doi: 10.1053/j.sodo.2004.05.005

11. Sena LMF, Sena PPM, Pereira HSG. Cephalometric analysis: Orthodontists versus oral radiologists. J World Fed Orthod. 2016;5(1):18-21. doi: 10.1016/j.ejwf.2016.02.002

12. Silveira HLD, Silveira HED. Reproducibility of cephalometric measurements made by three radiology clinics. Angle Orthod. 2006;76(3):394-9. doi:10.1043/0003-3219(2006)076[0394:RO CMMB]2.0.CO;2

13. Jabbal A, Cobourne M, Donaldson N, Bister D. Assessing lower incisor inclination change: a comparison of four cephalometric methods. Eur J Orthod. 2016;38(2):184-9. doi: 10.1093/ejo/ cjv027 